\title{
Identification of azurocidin as a potential periodontitis biomarker by a proteomic analysis of gingival crevicular fluid
}

\author{
Young-Jin Choi', Sun-Hee Heo', Jae-Mok Lee ${ }^{2}$ and Je-Yoel Cho ${ }^{1 *}$
}

\begin{abstract}
Background: The inflammatory disease periodontitis results in tooth loss and can even lead to diseases of the whole body if not treated. Gingival crevicular fluid (GCF) reflects the condition of the gingiva and contains proteins transuded from serum or cells at inflamed sites. In this study, we aimed to discover potential protein biomarkers for periodontitis in GCF proteome using LC-MS/MS.

Results: We identified 305 proteins from GCF of healthy individuals and periodontitis patients collected using a sterile gel loading tip by ESI-MS/MS coupled to nano-LC. Among these proteins, about 45 proteins were differentially expressed in the GCF proteome of moderate periodontitis patients when compared to the healthy individuals. We first identified azurocidin in the GCF, but not the saliva, as an upregulated protein in the periodontitis patients and verified its increased expression during periodontitis by ELISA using the GCF of the classified periodontitis patients compared to the healthy individuals. In addition, we found that azurocidin inhibited the differentiation of bone marrow-derived macrophages to osteoclasts.

Conclusions: Our results show that GCF collection using a gel loading tip and subsequent LC-MS/MS analysis following 1D-PAGE proteomic separation are effective for the analysis of the GCF proteome. Our current results also suggest that azurocidin could be a potential biomarker candidate for the early detection of inflammatory periodontal destruction by gingivitis and some chronic periodontitis. Our data also suggest that azurocidin may have an inhibitory role in osteoclast differentiation and, thus, a protective role in alveolar bone loss during the early stages of periodontitis.
\end{abstract}

\section{Background}

Periodontal diseases are a type of inflammatory disease that affect the periodontium surrounding and supporting the teeth and are caused by microorganisms that adhere to and grow on the surfaces of teeth. Most cases of destructive periodontitis are composed of aggressive and chronic periodontitis [1]. Half of the adults in the U.S. suffer from chronic periodontitis, which is the most general form of destructive periodontitis, and about $10 \%$ of the population is at a high risk for severe periodontitis [2]. It has been suggested that chronic periodontitis can lead to bone loss and tooth mortality, which might

\footnotetext{
* Correspondence: jeycho@knu.ac.kr

'Department of Biochemistry, School of Dentistry, Kyungpook National University, Daegu, Korea

Full list of author information is available at the end of the article
}

lead to further systemic diseases, e.g., cardiovascular disease and stroke $[3,4]$.

A diagnosis of periodontitis is established by traditionally used indices, e.g., bleeding upon probing and probing depth, which indicate the loss of periodontal tissue attachment to the teeth $[5,6]$. Additionally, radiography visualizes the loss of periodontal tissue, which supports the diagnosis by determining the amount of bone loss around the teeth [7]. However, these methods are only useful when attachment loss has occurred to some degree. For chair-side and single visits, more reliable biomarkers for periodontitis are needed to provide constant classification and customized treatment and for monitoring periodontal diseases $[8,9]$.

Gingival crevicular fluid (GCF) is bodily fluid that reflects the condition of the periodontium [10]. GCF contains various components that originate by transudation
C Biomed Central

(c) 2011 Choi et al; licensee BioMed Central Ltd. This is an Open Access article distributed under the terms of the Creative Commons Attribution License (http://creativecommons.org/licenses/by/2.0), which permits unrestricted use, distribution, and reproduction in any medium, provided the original work is properly cited. 
of the serum or inflammatory factors and are derived from the interaction between the bacterial biofilm and the cells of periodontal tissues [11,12]. Additionally, despite a large variation, the amount of GCF tends to increase with the severity of gingival inflammation [13]. In addition to these characterizations, the simple and noninvasive collection of GCF is required for the discovery of periodontitis biomarkers. However, GCF collection using filter paper strips and microcapillary tubes, two generally used methods, have drawbacks such as nonspecific binding of the analyte to paper fibers and the loss of the collected sample, respectively [10].

In previous decades, proteomic analysis has been successfully used for various purposes, such as the identification of binding partner proteins to certain factors and novel proteins derived under specific circumstances. In particular, proteomic technology has become an important tool for the discovery of protein/peptide biomarkers. Proteomic analysis of bodily fluids, e.g., blood, urine, and GCF, is widely used for biomarker discovery because of its easy accessibility for analysis and diagnosis [14].

In this study, we isolated GCF from periodontitis patients and healthy individuals using a gel loading tip. In an effort to discover potential protein biomarkers for periodontitis in GCF, protein samples from the GCF were used for the analysis of the GCF proteome using LC-MS/MS.

\section{Methods}

\section{Human GCF samples}

GCF samples were collected from periodontitis patients and healthy individuals for the identification of periodontitis biomarkers at the Department of Periodontology, School of Dentistry, Kyungpook National University. The standard protocol was approved by the IRB of Kyungpook National University Hospital (IRB NO. 74005 - 830). Informed consent was obtained from all donors.

\section{Clinical parameters and the establishment of a standard protocol for GCF collection}

To stratify the chronic gingivitis and chronic periodontitis patients, the clinical periodontal parameters from average 6 sites per individual were assessed at the initial examination for mean probing depth (PD), clinical attachment loss (CAL), bleeding upon probing (BOP), and the gingival index (GI) (Table 1) [15]. According to the criteria and complications, we divided the samples into normal $(\mathrm{N})$, chronic gingivitis $(\mathrm{GV})$, moderate periodontitis (MP), and severe periodontitis (SP) and collected GCF with a sterile gel loading tip (DASLAB, Spain). Each individual sample was collected from the sites of gingival sulcus with same classification of periodontitis according to our criteria. Because of the small volume of collected GCF (about 0.5 to $2 \mu \mathrm{l}$ per patient), all of the collected samples were directly diluted into $20 \mu \mathrm{l}$ of $0.9 \% \mathrm{NaCl}$ solution for the convenience of sample preparation. Diluted samples were centrifuged at $13,000 \mathrm{~g}\left(4^{\circ} \mathrm{C}\right)$ for $15 \mathrm{~min}$, and the supernatants were transferred to new tubes to remove contaminants such as tissue debris. The transferred samples were used for protein quantification and stored at $-70^{\circ} \mathrm{C}$ until further assay (Figure 1A). Among the $869 \mathrm{GCF}$ samples (161 normal, 229 gingivitis, 296 moderate periodontitis, and 183 severe periodontitis) collected from July 2009 to Aug. 2010, we used GCF samples without complications such as diabetes, arteriosclerosis, hepatitis, AIDS, hypertension, or pregnancy for LC-MS/MS analysis, western blotting, and ELISA.

\section{Collection of gingival tissue}

Gingival tissue samples were obtained from patients undergoing periodontal surgery at the Department of Periodontology, School of Dentistry, Kyungpook National University. The standard protocol was approved by the IRB of Kyungpook National University Hospital (IRB NO. 74005 - 830). Informed consent was obtained from all donors. Gingival tissues were classified as normal $(\mathrm{N})$, gingivitis (GV), moderate periodontitis (MP), or severe periodontitis (SP) according to criteria such as the gingival index considered immune reaction, probing depth, clinical attached loss, and bone loss on radiograph (Table 1). For western blotting, gingival tissues were isolated from 2 healthy individuals $(\mathrm{N}), 3$ with chronic gingivitis (GV), 3 with moderate periodontitis (MP), and 3 with severe periodontitis (SP).

\section{LC-ESI-MS/MS analysis following in-gel digestion}

We selected GCF samples collected from 11 normal (N) and 12 moderate periodontitis (MP) patients without systemic complications (Additional files 1) for analysis of the GCF proteomes using LC-MS/MS. Twenty micrograms of pooled samples was separated by $1 \mathrm{D}$ gel electrophoresis. Gels were stained with Bio-Safe Coomassie Stain solution (Bio-Rad, Hercules, CA) for $1 \mathrm{~h}$ and destained by incubation in $\mathrm{dd}_{2} \mathrm{O}$. In-gel tryptic digestion was performed as previously described [16]. Briefly, protein bands were excised from Coomassie-stained gels and destained. Disulfide bonds were reduced by treatment with $5 \mathrm{mM}$ Dithiothreitol (DTT)/25 mM ammonium bicarbonate (Sigma-Aldrich, St. Louis, MO) at $60^{\circ} \mathrm{C}$ for $30 \mathrm{~min}$, followed by alkylation with $55 \mathrm{mM}$ iodoacetamide (Sigma-Aldrich, St. Louis, MO) at RT for $30 \mathrm{~min}$. The gel pieces were dehydrated in $100 \%$ acetonitrile (ACN) (Sigma-Aldrich, St. Louis, MO) and dried. They were then subsequently rehydrated in $10 \mu \mathrm{l}$ of $25 \mathrm{mM}$ ammonium bicarbonate buffer containing $20 \mu \mathrm{g} / \mathrm{ml}$ 
Table 1 Criteria for the classification of collected GCF

\begin{tabular}{|c|c|c|c|c|}
\hline & $\mathrm{N}$ & GV & MP & SP \\
\hline \multirow[t]{2}{*}{ GI } & 0 & 1 & 2 & 3 \\
\hline & $\begin{array}{l}\text { Normal } \\
\text { gingiva }\end{array}$ & $\begin{array}{l}\text { mild inflammation, slight } \\
\text { change in color and slight } \\
\text { edema, no BOP }\end{array}$ & $\begin{array}{l}\text { moderate inflammation, } \\
\text { redness, edema, glazing, } \\
\text { BOP }\end{array}$ & $\begin{array}{l}\text { severe inflammation, marked redness and } \\
\text { edema, ulceration, tendency toward } \\
\text { spontaneous bleeding }\end{array}$ \\
\hline PD & $1 \mathrm{~mm}$ & $\leq 3 \mathrm{~mm}$ & $3-7 \mathrm{~mm}$ & $\geq 7 \mathrm{~mm}$ \\
\hline CAL & 0 & 0 & $<5 \mathrm{~mm}$ & $\geq 5 \mathrm{~mm}$ \\
\hline $\begin{array}{l}\text { Evidence of bone } \\
\text { loss on } \\
\text { radiograph }\end{array}$ & - & - & + & + \\
\hline
\end{tabular}

modified sequencing grade trypsin (Roche, Mammheim, Germany) and incubated overnight at $37^{\circ} \mathrm{C}$. The tryptic peptide mixture was eluted from the gel with $0.1 \%$ formic acid (Fluka, Switzerland).

LC-MS/MS analysis was performed using a Thermo Finnigan ProteomeX workstation LTQ linear ion trap MS/MS (Thermo Electron, San Jose, CA, USA) equipped with NSI sources (San Jose, CA) as previously reported $[17,18]$. Briefly, $12 \mu \mathrm{l}$ of peptide sample from the in-gel digestion was injected and loaded onto a peptide trap cartridge (Agilent, Palo Alto, CA). Trapped peptides were eluted onto a $10-\mathrm{cm}$ reversed-phase PicoFrit column packed in-house with $5 \mu \mathrm{m}, 300 \AA$ pore size C18 and then separated by gradient elution. The mobile phases consisted of $\mathrm{H}_{2} \mathrm{O}(\mathrm{A})$ and $\mathrm{ACN}(\mathrm{B})$, and both phases contained $0.1 \%(\mathrm{v} / \mathrm{v})$ formic acid. The gradient started at $2 \%$ $\mathrm{B}$, reached $60 \% \mathrm{~B}$ in $50 \mathrm{~min}, 80 \% \mathrm{~B}$ in the next $5 \mathrm{~min}$, and $100 \% \mathrm{~A}$ in the final $15 \mathrm{~min}$. Data-dependent acquisition (m/z 400-1800) was enabled. Each survey MS scan was followed by five MS/MS scans within $30 \mathrm{sec}$ with the dynamic exclusion option on. The dynamic exclusion option is a tool for the exclusion of basal peaks to

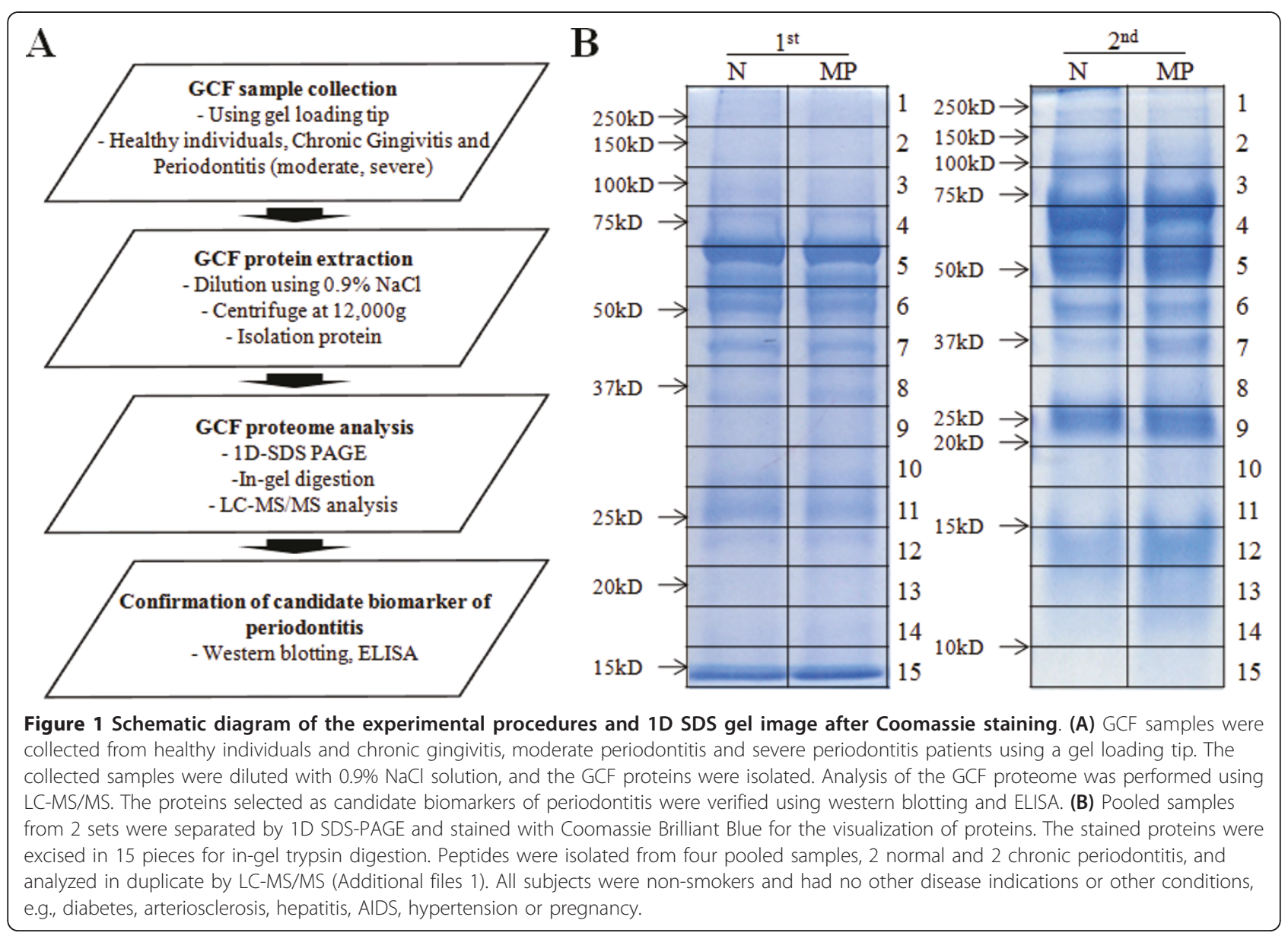


increase proteome coverage by removing background noise in MS/MS peaks.

\section{Data analysis}

Tandem mass spectra were extracted and charge state deconvoluted and deisotoped using Sorcerer 3.4 beta 2 (Sorcerer software 3.10.4, Sorcerer Web interface 2.2.0 r334 and Trans-Proteomic Pipeline 2.9.5), as previously reported [18]. All MS/MS samples were analyzed using SEQUEST (Thermo Finnigan, San Jose, CA; version v.27, rev. 11). SEQUEST was set to search the IPI Human 3.49 database (IPI ver. 3.49, 74,017 entries) assuming semiTrypsin as the digestion enzyme. SEQUEST search parameters were set to a fragment ion mass tolerance of $1.0 \mathrm{Da}$ and a parent ion tolerance of $1.5 \mathrm{Da}$. Oxidation of methionine and iodoacetamide modification of cysteine were specified as fixed modifications. Scaffold (version Scaffold02_04_00, Proteome Software Inc., Portland, OR) calculates the quantitative value number by normalizing the spectral counts across our Scaffold experiment. For improved false-positive statistics, the decoy option was selected during the data search process in the Sorcerer program, which improves the quality of the results by reducing the effects of noise. Comparative data analysis using Scaffold was subsequently used to validate MS/MSbased peptide and protein identifications. Protein identifications were accepted if they could be established at a confidence level greater than $95.0 \%$ probability, as specified by the Peptide Prophet algorithm [19]. Protein probabilities were assigned by the Protein Prophet algorithm [20]. Proteins that contained similar peptides and that could not be differentiated based on the MS/MS analysis alone were grouped to satisfy the principles of parsimony. The peptide false positive (FPR) rate was calculated using the Scaffold software. For each charge state, incorrect assignments were tabulated to calculate the FPRi = [(\#Assigned Incorrect at 95\% probability)/(Total\# Incorrect Assigned) $]^{*} 100$, with $i$ being the charge state. The assignment is considered correct if it is associated with a protein that has a $95 \%$ probability, according to the Protein Prophet algorithm, and if a minimum of 2 peptides are matched with the protein sequence, each with a $95 \%$ probability, based on the Peptide Prophet algorithm. After identifying the proteins, each dataset was used for a subtractive analysis by quantitative value, which normalizes the spectral counts in the Scaffold program.

\section{Western Blot}

Western blots were performed as previously reported [21]. Briefly, $5 \mu \mathrm{g}$ of gingival tissue was separated by $15 \%$ SDS-PAGE (Elpis-Biotech, Korea) for azurocidin. After electrophoresis, the proteins were transferred to PVDF membrane (Roche, USA), which was incubated with antihuman azurocidin antibody (Santa Cruz, CA) (1:1000) and $\beta$-actin antibody (Abcam, Cambridge, MA) (1:2000), followed by an anti-rabbit IgG antibody (1:2000) for azurocidin and an anti-mouse IgG antibody (1:2000) for $\beta$-actin.

\section{ELISA}

For the verification of azurocidin expression in GCF, samples were selected from $31 \mathrm{~N}, 36$ gingivitis (GV), $59 \mathrm{MP}$, and 30 severe periodontitis (SP) patients (Additional files 2). Selected samples were collected from non-smokers and subjects having no complications (Additional files 2). The ELISA (Cusabio, China) for azurocidin was performed following the manufacturer's instructions. Briefly, samples were added in a well and incubated for $2 \mathrm{~h}\left(37^{\circ} \mathrm{C}\right)$. The liquid from each well was removed, and $100 \mu \mathrm{l}$ of biotinantibody working solution was then added to each well for $1 \mathrm{~h}\left(37^{\circ} \mathrm{C}\right)$. The mixture was removed and washed with the provided buffer $(350 \mu \mathrm{l})$ using a multi-channel pipette. After washing, HRP-avidin working solution was added to each well and incubated for $1 \mathrm{~h}\left(37^{\circ} \mathrm{C}\right)$. After washing, TMB substrate was added and incubated for $30 \mathrm{~min}$ $\left(37^{\circ} \mathrm{C}\right)$, and the reaction was stopped by adding $50 \mu \mathrm{l}$ of Stop Solution to each well. The optical density of each well was determined using a microplate reader set to $450 \mathrm{~nm}$.

\section{Osteoclast differentiation and TRAP staining}

Bone marrow cells were isolated from the tibiae and femora of 5-week-old BALB/c mice and cultured with $\alpha$ MEM containing $10 \%$ FBS in a humidified incubator $(5 \%$ $\mathrm{CO}_{2}$ ) at $37^{\circ} \mathrm{C}$. After $24 \mathrm{~h}$, non-adherent cells were centrifuged to obtain bone marrow-derived macrophage (BMM) cells and incubated for use as adherent BMM for 3 days in the presence of $20 \mathrm{ng} / \mathrm{ml}$ macrophage colony stimulating factor (M-CSF) (Peprotech, USA). For the osteoclastogenesis experiments, BMM cells were cultured in the presence of $20 \mathrm{ng} / \mathrm{ml}$ RANKL (R\&D, USA) and $20 \mathrm{ng} / \mathrm{ml} \mathrm{M-CSF}$ with azurocidin (R\&D, USA) at the indicated concentration. TRAP staining was performed according to the manufacturer's instructions (Sigma, USA) [22].

\section{Statistical analysis}

The data are presented as the means \pm SE. The statistical significance of the results was assessed using one-way ANOVA, followed by Student's t-test for unpaired samples. All p-values were derived from two-tailed statistical tests, and a p-value $<0.05$ was regarded as statistically significant.

\section{Results}

\section{General strategy and GCF protein visulalization by Coomassie staining}

To analyze the GCF proteomes by LC-MS/MS, we selected 11 normal $(\mathrm{N})$ and 12 moderate periodontitis 
(MP) patients without systemic complications (Additional files 1). For a representative group of periodontitis, MP samples were selected for LC-MS/MS analysis. Proteins in the pooled samples were separated by SDSPAGE. The patterns of SDS-PAGE-separated proteins were visualized by Coomassie staining (Figure 1B). In the region near $37 \mathrm{kDa}\left(8^{\text {th }}\right.$ band of the first pool and $7^{\text {th }}$ band of the second pool), a protein band was stained more intensely in MP compared to $\mathrm{N}$.

\section{Analysis of the GCF proteome by LC-MS/MS}

Proteins from 4 different pooled GCF samples were identified by the duplicate LC-MS/MS analysis of each (total of 8 analyses). By searching the human IPI databases with a protein identification criteria of at least 2 peptides, a total of 305 proteins were identified from the combined analysis of both the $\mathrm{N}$ and MP samples (Additional files 3). These data revealed that the reverse peptide hit rate was $0.94 \pm 0.1 \%$ of total peptide hits using the decoy protein database. After normalization of the spectral counts by total ion currents in the Scaffold program, we calculated the average spectral counts of 4 analyses (duplicate analysis of two sets of experiments) in each $\mathrm{N}$ and MP sample and then calculated the fold ratio of $\mathrm{MP}$ vs. $\mathrm{N}(\mathrm{MP} / \mathrm{N})$. The results revealed that 25 proteins demonstrated a 2 -fold or higher ratio of average spectral counts in the MP samples (Table 2), and 20 proteins demonstrated a 2 -fold or higher ratio of average spectral counts in the $\mathrm{N}$ samples (Table 3 ). Additionally, 45 proteins were classified based on biological process, cellular component, and molecular function using the UniProt database (Tables 2 and 3). By searching the NCBI bacterial database, proteins from bacteria known to cause periodontitis were also identified (Additional files 4).

\section{Verification of azurocidin expression in GCF using ELISA}

Among the proteins upregulated in periodontitis, azurocidin was first selected to validate on a larger scale because it is known to be secreted by neutrophils upon inflammatory challenges and because it is an attractant for monocyte infiltration into inflamed tissues $[23,24]$. Thus, azurocidin levels were measured by western blotting and ELISA in the same samples used for LC-MS/ MS analysis (Figures 2A and 2B). Using an ELISA, azurocidin was detected at an 8.8-fold higher level (10.6 pg/ $\mathrm{ml}$ in $\mathrm{N}$ and $92.5 \mathrm{pg} / \mathrm{ml}$ in MP) in the GCF of MP compared to N. This dramatic increase may be due in part to the higher sensitivity of ELISA. To avoid prejudice against a small sample size, we performed an ELISA assay of azurocidin with $31 \mathrm{~N}, 36$ gingivitis (GV), 59 $\mathrm{MP}$, and 30 severe periodontitis (SP) patients (Additional files 2), and the average levels of azurocidin in each sample were $40.8 \mathrm{pg} / \mathrm{ml}, 136.6 \mathrm{pg} / \mathrm{ml}, 118.3 \mathrm{pg} / \mathrm{ml}$, and $85.3 \mathrm{pg} / \mathrm{ml}$, respectively. With a $50 \mathrm{pg} / \mathrm{ml}$ cutoff, the specificity is $74.2 \%$, and the sensitivities are $66.7 \%$ in $\mathrm{GV}, 76.3 \%$ in $\mathrm{MP}$, and $60.0 \%$ in SP patients (Figure $2 \mathrm{C}$, Table 4). Additionally, azurocidin was also expressed at a higher level in the gingival tissue of periodontitis patients compared to healthy controls in the western blotting assay (Figure 3). The detected sizes of azurocidin were approximately $27 \mathrm{kDa}$.

\section{Effect of azurocidin on osteoclastogenesis}

Severe periodontitis (SP) results in alveolar bone loss, but not during the early stages of gingivitis. It has been suggested that the regulatory factors of the immune response can affect bone metabolism. Thus, we tested if azurocidin could affect osteoclast differentiation. On day 3 , TRAP staining was performed on azurocidin-treated cultures. Osteoclast differentiation of BMM was decreased by the azurocidin treatment (Figure 4), which suggests that high levels of azurocidin at an early stage may have a protective role in osteoclast-activated alveolar bone loss.

\section{Discussion}

In this study, using biologically-independent duplicate experiments of an analytically duplicate LC-MS/MS analysis of the GCF from healthy individuals (N) and moderate periodontitis (MP) patients, 305 proteins were identified. Of these proteins, 45 were significantly up- or downregulated in the GCF of MP patients. We collected 869 GCF samples from patients using a sterile gel loading tip. Among these, we used GCF samples from patients without complications such as diabetes, arteriosclerosis, hepatitis, AIDS, hypertension, or pregnancy for LC-MS/MS analysis, western blotting, and ELISA. We also validated that the azurocidin levels were elevated in periodontitis patients by ELISA in about 150 samples from stratified periodontitis samples and healthy controls.

In our study, for GCF collection, we tried several methods including paper and 26 gauge needles; however, we found that fine gel loading tips are a useful and convenient method for the collection of as much GCF as possible, which resulted in a shortened collection time, a decreased loss of isolated volume and a reduction in the inconvenience/hostility of patients during collection. We identified 305 proteins from the analysis of the GCF proteome by GeLC-MS/MS and also first detected azurocidin as a component of GCF (Additional files 3). In addition, we showed that azurocidin has an effect on the osteoclastogenesis of BMM. Proteins from various bacteria were also identified by searching the LC-MS/MS data against bacterial databases (Additional files 4). However, we could not find significant differences in the bacterial proteomes of the GCF of $\mathrm{N}$ and 
Table 2 List of upregulated proteins in periodontitis GCF

\begin{tabular}{|c|c|c|c|c|c|c|c|c|c|c|}
\hline$\#$ & Identified Proteins & $\begin{array}{l}\text { Accession } \\
\text { Number }\end{array}$ & Biological process & Cellular component & Molecular function & $\begin{array}{l}\text { Molecular } \\
\text { Weight }\end{array}$ & $\mathrm{N}$ & MP & $\begin{array}{l}\text { MP/N } \\
\text { fold }\end{array}$ & $\begin{array}{l}\text { N/MP } \\
\text { fold }\end{array}$ \\
\hline 1 & Catalase & IPI00465436 & hydrogen peroxide removal & peroxisome & $\begin{array}{c}\text { mitogen } \\
\text { oxidoreductase } \\
\text { peroxidase }\end{array}$ & $60 \mathrm{kDa}$ & $0.3 \pm 0.4$ & $3.0 \pm 1.4$ & 12.0 & 0.1 \\
\hline 2 & $\begin{array}{l}\text { Adenylyl cyclase-associated } \\
\text { protein } 1\end{array}$ & IPI00008274 & signal transduction & cell membrane & actin binding & $52 \mathrm{kDa}$ & $0.5 \pm 0.7$ & $5.8 \pm 6.0$ & 11.5 & 0.1 \\
\hline 3 & Plastin-2 & IPI00010471 & T cell activation & cell junction & calcium ion binding & $70 \mathrm{kDa}$ & $2.0 \pm 0.7$ & $15.0 \pm 12.7$ & 7.5 & 0.1 \\
\hline 4 & Alpha-actinin-1 & IPI00013508 & $\begin{array}{c}\text { negative regulation of cellular } \\
\text { component }\end{array}$ & cytosol & actin binding & $103 \mathrm{kDa}$ & $1.5 \pm 0.7$ & $10.3 \pm 13.1$ & 6.8 & 0.1 \\
\hline 5 & Fibrinogen beta chain & IPI00298497 & platelet activation & $\begin{array}{l}\text { external side of } \\
\text { plasma membrane }\end{array}$ & cell surface binding & $56 \mathrm{kDa}$ & $0.8 \pm 0.4$ & $4.8 \pm 1.8$ & 6.3 & 0.2 \\
\hline 6 & Hornerin & IPI00398625 & keratinization & & $\begin{array}{l}\text { developmental } \\
\text { protein }\end{array}$ & $282 \mathrm{kDa}$ & $1.0 \pm 1.4$ & $5.5 \pm 4.2$ & 5.5 & 0.2 \\
\hline 7 & Isoform 1 of Myosin-9 & IPI00019502 & cell shape & cytosol & motor protein & $227 \mathrm{kDa}$ & $4.8 \pm 3.9$ & $23.5 \pm 26.2$ & 4.9 & 0.2 \\
\hline 8 & Myeloblastin & IPI00027409 & collagen degradation & & serine protease & $28 \mathrm{kDa}$ & $2.3 \pm 0.4$ & $11.0 \pm 2.8$ & 4.9 & 0.2 \\
\hline 9 & Azurocidin & IPI00022246 & chemotaxis & azurophil granule & antimicrobial & $27 \mathrm{kDa}$ & $2.0 \pm 0.7$ & $9.3 \pm 1.8$ & 4.6 & 0.2 \\
\hline 10 & $\begin{array}{c}\text { Isoform } 1 \text { of Fibrinogen alpha } \\
\text { chain }\end{array}$ & IPI00021885 & blood coagulation & Secreted & cell surface binding & $95 \mathrm{kDa}$ & $0.8 \pm 1.1$ & $3.0 \pm 2.1$ & 4.0 & 0.3 \\
\hline 11 & Leukocyte elastase & IPI00027769 & inflammatory response & secretory granule & Serine protease & $29 \mathrm{kDa}$ & $5.0 \pm 4.2$ & $16.0 \pm 3.5$ & 3.2 & 0.3 \\
\hline 12 & Matrix metalloproteinase-9 & IPI00027509 & collagen degradation & extracellular matrix & metalloprotease & $78 \mathrm{kDa}$ & $3.8 \pm 3.9$ & $10.5 \pm 12.7$ & 2.8 & 0.4 \\
\hline 13 & HBD Hemoglobin subunit delta & IPI00473011 & oxygen transport & hemoglobin complex & oxygen binding & $16 \mathrm{kDa}$ & $\begin{array}{l}34.8 \pm \\
7.4\end{array}$ & $94.8 \pm 63.3$ & 2.7 & 0.4 \\
\hline 14 & Coronin-1A & IPI00010133 & innate immune response & cytoplasm & $\begin{array}{l}\text { actin filament } \\
\text { binding }\end{array}$ & $51 \mathrm{kDa}$ & $5.0 \pm 2.8$ & $13.0 \pm 13.4$ & 2.6 & 0.4 \\
\hline 15 & Rho GDP-dissociation inhibitor 2 & IPI00003817 & immune response & cytoplasm & GTPase activator & $23 \mathrm{kDa}$ & $5.0 \pm 3.5$ & $12.0 \pm 4.9$ & 2.4 & 0.4 \\
\hline 16 & Keratin, type II cytoskeletal 5 & IPI00009867 & assembly & intermediate filament & structural constituent & $62 \mathrm{kDa}$ & $\begin{array}{c}9.8 \pm \\
11.0\end{array}$ & $21.8 \pm 13.1$ & 2.2 & 0.4 \\
\hline 17 & Macrophage-capping protein & IPI00027341 & assembly & cytoplasm nucleus & actin binding & $39 \mathrm{kDa}$ & $1.8 \pm 2.5$ & $3.8 \pm 1.8$ & 2.1 & 0.5 \\
\hline 18 & $\begin{array}{l}\text { HBA2 Hemoglobin subunit } \\
\text { alpha }\end{array}$ & IPI00410714 & oxygen transport & hemoglobin complex & oxygen binding & $15 \mathrm{kDa}$ & $\begin{array}{c}49.8 \pm \\
20.9\end{array}$ & $\begin{array}{c}105.5 \pm \\
66.5\end{array}$ & 2.1 & 0.5 \\
\hline 19 & Keratin, type II cytoskeletal 1 & IPI00220327 & fibrinolysis & intermediate filament & structural constituent & $66 \mathrm{kDa}$ & $\begin{array}{l}93.0 \pm \\
79.2\end{array}$ & $\begin{array}{c}196.5 \pm \\
193.0\end{array}$ & 2.1 & 0.5 \\
\hline 20 & Annexin A3 & IPI00024095 & defense response to bacterium & phagocytic vesicle & $\begin{array}{l}\text { calcium-dependent } \\
\text { phospholipid binding }\end{array}$ & $36 \mathrm{kDa}$ & $4.5 \pm 4.2$ & $9.5 \pm 0.7$ & 2.1 & 0.5 \\
\hline 21 & Hemoglobin subunit beta & IPI00654755 & oxygen transport & hemoglobin complex & hypotensive agent & $16 \mathrm{kDa}$ & $\begin{array}{c}74.5 \pm \\
7.1\end{array}$ & $\begin{array}{c}155.8 \pm \\
83.8\end{array}$ & 2.1 & 0.5 \\
\hline 22 & Keratin, type I cytoskeletal 9 & IPI00019359 & organization & intermediate filament & structural constituent & $62 \mathrm{kDa}$ & $\begin{array}{l}31.0 \pm \\
22.6\end{array}$ & $64.8 \pm 63.3$ & 2.1 & 0.5 \\
\hline 23 & $\begin{array}{c}\text { Keratin, type II cytoskeletal } 2 \\
\text { epidermal }\end{array}$ & IPI00021304 & keratinization & intermediate filament & structural constituent & $66 \mathrm{kDa}$ & $\begin{array}{l}32.3 \pm \\
39.2\end{array}$ & $65.0 \pm 72.1$ & 2.0 & 0.5 \\
\hline 24 & Actin-related protein 2 & IPI00005159 & cellular component & cytoplasm & actin binding & $45 \mathrm{kDa}$ & $0.8 \pm 1.1$ & $1.5 \pm 0.7$ & 2.0 & 0.5 \\
\hline 25 & S100-A9 & IPI00027462 & chemotaxis & extracellular region & $\begin{array}{l}\text { calcium ion-binding } \\
\text { protein }\end{array}$ & $13 \mathrm{kDa}$ & $\begin{array}{c}44.8 \pm \\
1.1\end{array}$ & $88.5 \pm 1.4$ & 2.0 & 0.5 \\
\hline
\end{tabular}


Table 3 List of downregulated proteins in periodontitis GCF.

\begin{tabular}{|c|c|c|c|c|c|c|c|c|c|c|}
\hline$\#$ & Identified Proteins & $\begin{array}{l}\text { Accession } \\
\text { Number }\end{array}$ & Biological process & $\begin{array}{l}\text { Cellular } \\
\text { component }\end{array}$ & $\begin{array}{l}\text { Molecular } \\
\text { function }\end{array}$ & $\begin{array}{l}\text { Molecular } \\
\text { Weight }\end{array}$ & $\mathrm{N}$ & MP & $\begin{array}{l}\text { MP/N } \\
\text { fold }\end{array}$ & $\begin{array}{l}\text { N/MP } \\
\text { fold }\end{array}$ \\
\hline 1 & Cystatin-A & IPI00032325 & keratinocyte & cytoplasm & $\begin{array}{l}\text { cysteine-type } \\
\text { endopeptidase } \\
\text { inhibitor activity }\end{array}$ & $11 \mathrm{kDa}$ & $4.5 \pm 3.5$ & $2.3 \pm 1.1$ & 0.5 & 2.0 \\
\hline 2 & Thymidine phosphorylase & IPI00292858 & chemotaxis & & glycosyltransferase & $50 \mathrm{kDa}$ & $7.5 \pm 2.8$ & $3.8 \pm 0.4$ & 0.5 & 2.0 \\
\hline 3 & Cystatin-B & IPI00021828 & & $\begin{array}{l}\text { cytoplasm } \\
\text { nucleus }\end{array}$ & protease inhibitor & $11 \mathrm{kDa}$ & $11.0 \pm 5.7$ & $5.3 \pm 1.1$ & 0.5 & 2.1 \\
\hline 4 & Cystatin-SN & IPI00305477 & & secreted & $\begin{array}{l}\text { cysteine-type } \\
\text { endopeptidase } \\
\text { inhibitor activity }\end{array}$ & $16 \mathrm{kDa}$ & $13.5 \pm 0.7$ & $6.3 \pm 2.5$ & 0.5 & 2.2 \\
\hline 5 & $\begin{array}{c}\text { IGKV3D-15 Myosin-reactive immunoglobulin light chain } \\
\text { variable region }\end{array}$ & IPI00549330 & & & & $13 \mathrm{kDa}$ & $6.3 \pm 0.4$ & $2.8 \pm 0.4$ & 0.4 & 2.3 \\
\hline 6 & Nucleoside diphosphate kinase B & IPI00026260 & $\begin{array}{l}\text { transcription } \\
\text { regulation }\end{array}$ & $\begin{array}{l}\text { cytoplasm } \\
\text { nucleus }\end{array}$ & kinase & $17 \mathrm{kDa}$ & $6.0 \pm 3.5$ & $2.5 \pm 1.4$ & 0.4 & 2.4 \\
\hline 7 & 14-3-3 protein epsilon & IPI00000816 & host-virus interaction & cytoplasm & $\begin{array}{l}\text { histone } \\
\text { deacetylase } \\
\text { binding }\end{array}$ & $29 \mathrm{kDa}$ & $9.0 \pm 1.4$ & $3.5 \pm 3.5$ & 0.4 & 2.6 \\
\hline 8 & Prolactin-inducible protein & IPI00022974 & & secreted & actin binding & $17 \mathrm{kDa}$ & $15.0 \pm 12.0$ & $5.3 \pm 6.0$ & 0.4 & 2.9 \\
\hline 9 & alpha-2-glycoprotein 1, zinc & IPI00166729 & immune response & secreted & $\begin{array}{l}\text { transmembrane } \\
\text { transporter activity }\end{array}$ & $34 \mathrm{kDa}$ & $13.0 \pm 2.8$ & $4.5 \pm 2.8$ & 0.3 & 2.9 \\
\hline 10 & Polymeric immunoglobulin receptor & IPI00004573 & & $\begin{array}{l}\text { membrane } \\
\text { secreted }\end{array}$ & protein binding & $83 \mathrm{kDa}$ & $76.0 \pm 34.6$ & $\begin{array}{c}25.3 \pm \\
31.5\end{array}$ & 0.3 & 3.0 \\
\hline 11 & $\begin{array}{l}\text { Lipopolysaccharide-responsive and beige-like anchor } \\
\text { protein }\end{array}$ & IPI00002255 & & $\begin{array}{l}\text { cell } \\
\text { membrane }\end{array}$ & protein binding & $319 \mathrm{kDa}$ & $4.8 \pm 4.6$ & $1.5 \pm 0.7$ & 0.3 & 3.2 \\
\hline 12 & IGL@ protein & IPI00555945 & & & & $25 \mathrm{kDa}$ & $69.0 \pm 27.6$ & $\begin{array}{c}21.5 \pm \\
13.4\end{array}$ & 0.3 & 3.2 \\
\hline 13 & Heat shock protein beta-1 & IPI00025512 & stress response & $\begin{array}{l}\text { cytoplasm } \\
\text { cytoskeleton } \\
\text { nucleus }\end{array}$ & $\begin{array}{l}\text { identical protein } \\
\text { binding }\end{array}$ & $23 \mathrm{kDa}$ & $7.8 \pm 1.1$ & $2.3 \pm 1.8$ & 0.3 & 3.4 \\
\hline 14 & Glutathione S-transferase P & IPI00219757 & anti-apoptosis & cytoplasm & $\begin{array}{l}\text { glutathione } \\
\text { transferase activity }\end{array}$ & $23 \mathrm{kDa}$ & $34.5 \pm 30.4$ & $\begin{array}{c}10.0 \pm \\
9.2\end{array}$ & 0.3 & 3.5 \\
\hline 15 & S100-A2 & IPI00019869 & $\begin{array}{l}\text { endothelial cell } \\
\text { migration }\end{array}$ & & $\begin{array}{l}\text { calcium ion } \\
\text { binding }\end{array}$ & $11 \mathrm{kDa}$ & $4.5 \pm 0.7$ & $1.3 \pm 0.4$ & 0.3 & 3.6 \\
\hline 16 & Glutathione transferase omega-1 & IPI00019755 & & cytoplasm & $\begin{array}{l}\text { glutathione } \\
\text { transferase activity }\end{array}$ & $28 \mathrm{kDa}$ & $4.0 \pm 1.4$ & $1.0 \pm 0.7$ & 0.3 & 4.0 \\
\hline 17 & Carbonyl reductase [NADPH] 1 & IPI00295386 & oxidation reduction & cytoplasm & oxidoreductase & $30 \mathrm{kDa}$ & $7.8 \pm 3.2$ & $1.3 \pm 1.1$ & 0.2 & 6.2 \\
\hline 18 & CRISP3 CDNA FLJ75207 & IPI00004798 & & $\begin{array}{l}\text { extracellular } \\
\text { region }\end{array}$ & & $29 \mathrm{kDa}$ & $7.0 \pm 7.8$ & $1.0 \pm 1.4$ & 0.1 & 7.0 \\
\hline 19 & Isoform 1 of Serpin B3 & IPI00022204 & & cytoplasm & $\begin{array}{l}\text { serine protease } \\
\text { inhibitor }\end{array}$ & $45 \mathrm{kDa}$ & $4.5 \pm 2.1$ & $0.5 \pm 0.0$ & 0.1 & 9.0 \\
\hline 20 & Aldo-keto reductase family 1 member $\mathrm{B} 10$ & IPI00105407 & oxidation reduction & cytoplasm & oxidoreductase & $36 \mathrm{kDa}$ & $4.8 \pm 3.2$ & $0.3 \pm 0.4$ & 0.1 & 19.0 \\
\hline
\end{tabular}




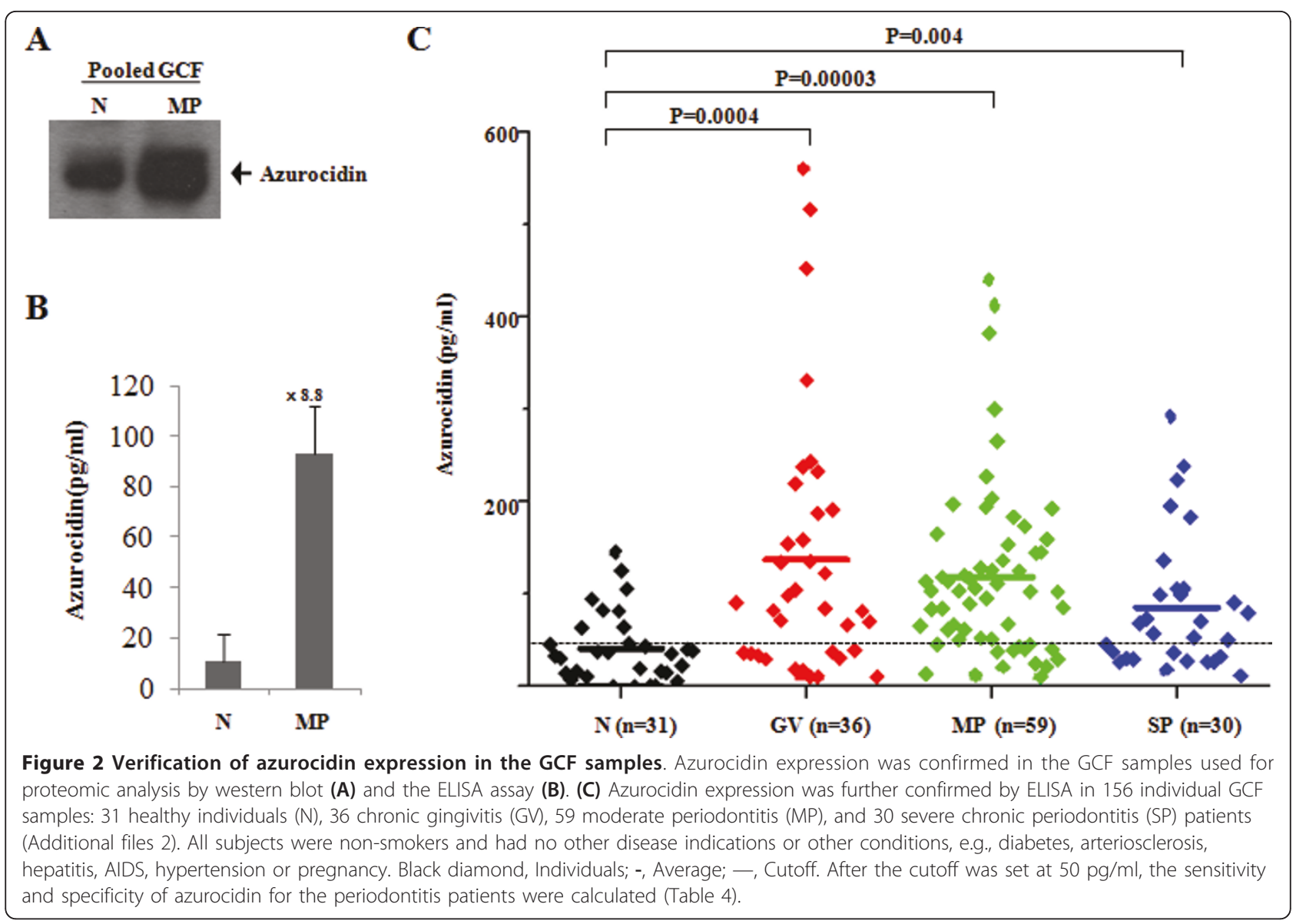

MP patients. For the further analysis of bacterial proteins, more classified samples and an efficient isolation method for bacterial proteins are needed.

Genomic and proteomic studies were performed to discover biologically-regulated signatures in periodontitis patients. Recently, the profiling of periodontitis-related molecules was reported. In 2008, a transcriptome analysis of gingival tissue was performed using 54,675 probe sets in 64 healthy sites and 183 inflamed sites [5]. The study reported 12,744 differentially expressed probe sets, which classified 16 groups related to functions such as apoptosis, the antimicrobial humoral response, and antigen presentation, as determined by gene ontology analysis. There were also proteomic studies on GCF itself. The GCF of a healthy donor was collected using sterile blotting paper cones, and serum albumin, $\alpha$-defensins 1-4, cystatin A, statherin, and basic PB salivary peptide were detected in the acidic extracts of GCF using HPLC-ESI-MS [25]. In another study, GCF samples collected from inflamed periodontal sites using sterile glass microcapillary tubes were analyzed using MALDI-TOF/ TOF MS and LC-ESI-MS/MS. Among the 66 proteins identified in human GCF, 43 proteins, which included actin, profilin, cofilin, and gelsolin, were first reported in GCF [26]. In a recent study, 40 GCF samples were collected from 5 healthy individuals and 5 aggressive periodontitis patients using sterile periopaper strips and analyzed by LC-MS, a label-free mass spectrometry. Among the 154 identified proteins, annexin-1 was expressed at a 5-fold higher level in healthy individuals, and L-plastin (plastin-2/LCP1) was detected only in periodontitis patients [27].

In accordance with a previous report, myeloperoxidase, myosin 9, annexin A3, profilin-1, L-plastin

Table 4 Comparison of studies that have reported on the identification of the GCF proteome

\begin{tabular}{lcccc}
\hline & $\mathbf{N}(\mathbf{n}=\mathbf{3 1})$ & $\mathbf{G V}(\mathbf{n}=\mathbf{3 6})$ & MP $(\mathbf{n}=\mathbf{5 9 )}$ & $\mathbf{S P}(\mathbf{n}=\mathbf{3 0})$ \\
\hline Average $(\mathbf{p g} / \mathrm{ml})$ & 40.8 & 136.6 & 118.3 & -35.3 \\
\hline Specificity (\%) & 74.2 & - & - & - \\
\hline Sensitivity (\%) & - & 66.7 & 76.3 & 60.0 \\
\hline
\end{tabular}




Figure 3 Azurocidin expression in gingival tissues by western blot. Protein expression levels of azurocidin were confirmed in gingival tissue
using western blotting. Gingival tissues were sorted by the stage of chronic gingivitis and periodontitis. The gingival tissues used for the
confirmation of azurocidin expression were from 2 healthy individuals ( $\mathrm{N}$ ) and 3 chronic gingivitis (GV), 3 moderate periodontitis (MP), and 3
severe chronic periodontitis (SP) patients. The detected sizes of azurocidin were approximately $27 \mathrm{kDa}$. After loading $5 \mu \mathrm{g}$ of protein, anti-human
azurocidin and anti- $\beta$-actin antibodies were used for detection. Overall, azurocidin expression was higher in periodontitis patients as compared
to healthy individuals.

(plastin-2/LCP1), S100A8, and S100A9 were detected at higher levels in chronic periodontitis patients compared to healthy individuals. The expression of cystatin-B was decreased in periodontitis patients compared to healthy controls [27]. Although cornifin-A and S100-P were identified by small peptide hits, S100-P was upregulated and cornifin-A was downregulated in the GCF of periodontitis patients compared to healthy individuals, in both our study and the previous study [27]. Additionally, we identified three proteins, azurocidin, neutrophil elastase 2 (ELA2), and myeloperoxidase (proteinase 3), that are known to be found in azurophil granules, the specialized lysosomes of neutrophils. These three proteins were consistently detected at higher levels in the GCF of chronic periodontitis patients (Table 2). Azurocidin, ELA2, and myeloperoxidase are located in a cluster on chromosome 19 and are constituents of azurophil granules during neutrophil differentiation [28].

Azurocidin is also known as heparin-binding protein (HBP) or cationic antimicrobial protein of $37 \mathrm{kDa}$ (CAP37) [29]. Azurocidin, a member of the serine proteases, is homologous to cathepsin G, elastase, and

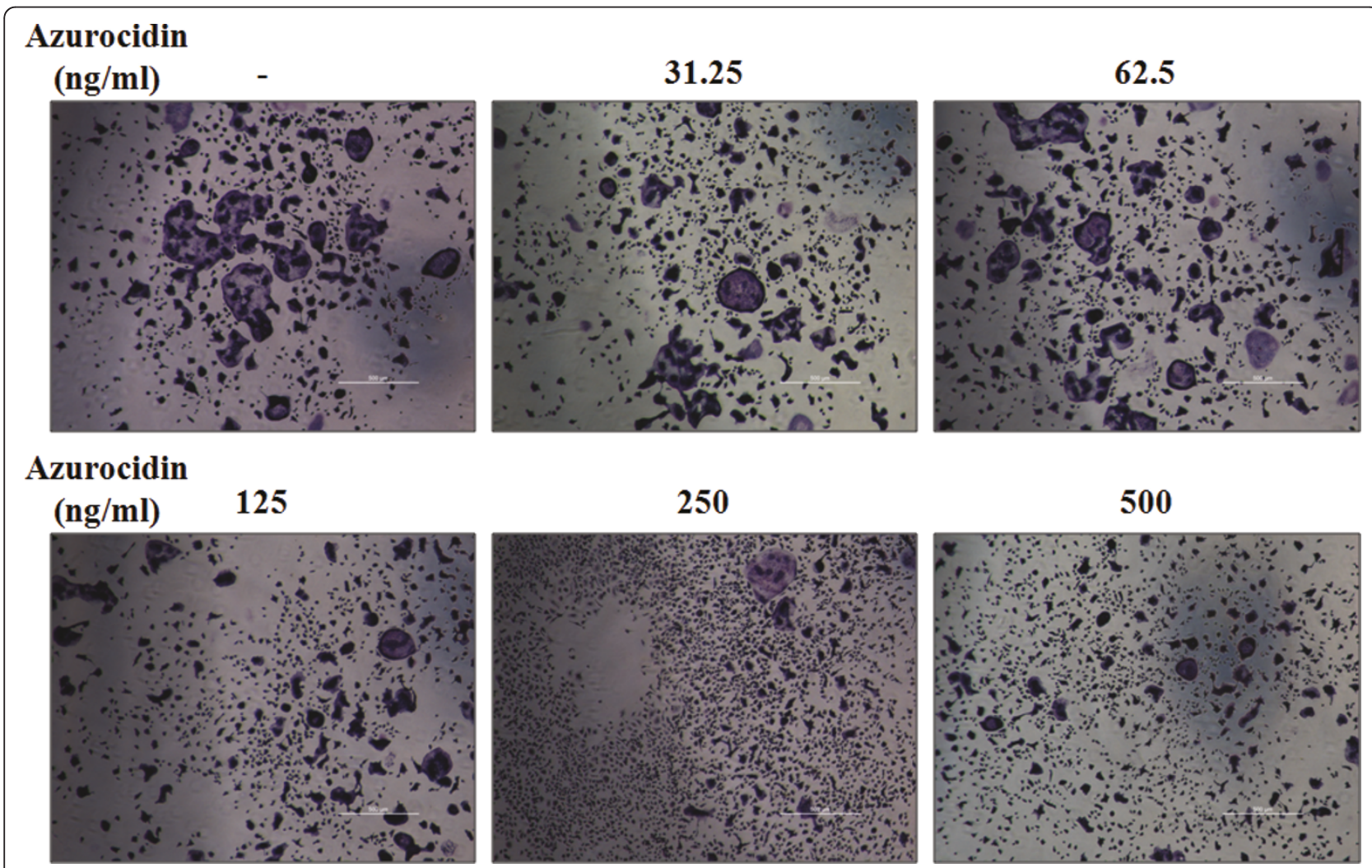

Figure 4 Inhibition of osteoclast differentiation by azurocidin. Mouse bone marrow monocytes (BMM) isolated from BALB/C mice were incubated in media containing RANKL $(20 \mathrm{ng} / \mathrm{ml})$ plus M-CSF $(20 \mathrm{ng} / \mathrm{ml})$ with the given concentration of azurocidin for 3 days. Osteoclast differentiation was evaluated by TRAP staining. The fused osteoclast cells revealed by TRAP staining were decreased with increasing dosages of azurocidin. 
proteinase 3 (PR-3; myeloblastin) but is known to lack proteolytic activity [30,31]. Azurocidin was first identified as a cationic antimicrobial protein (CAP) in human polymorphonuclear granulocyte (PMN) granules and exhibits an antimicrobial activity against Gram-negative bacteria (Salmonella typhimurium), Gram-positive bacteria (Staphylococcus aureus) and fungi (Candida albicans) $[29,32,33]$. Recombinant azurocidin induces the release of interleukin- 6 and tumor necrosis factor-alpha (TNF- $\alpha$ ) from human monocytes upon lipopolysaccharide (LPS) stimulation [34]. During the extravasation cascade of PMN, azurocidin serves as an alarmin and is released from infection sites to activate inflammatory cells [23].

In this study and for the first time, we identified azurocidin in GCF as a periodontitis biomarker. Through mass spectrometry, we determined that the azurocidin level is highly elevated in the GCF of chronic periodontitis patients (Table 2), and we also confirmed these results in different stages of periodontitis using an ELISA analysis (Figure 2C). Azurocidin levels are higher in GV and MP, compared to SP, and might serve as a promising biomarker for the development of the early diagnosis of periodontitis.

Periodontitis is a disease that affects the immune system and results in alveolar bone loss at its severe stages. Evidence has accumulated on the crosstalk between the immune and bone systems [35-38]. Immune response cytokines, such as TNF- $\alpha$, interleukin, and interferon, affect the differentiation and activity of osteoclasts and bone resorption. In addition, immune cells produce and release key factors (RANKL and M-CSF) for osteoclastogenesis. In regards to this aspect, we have shown the inhibitory effect of azurocidin on osteoclastogenesis from BMM (Figure 4). Thus, it is suggested that azurocidin elevation during gingivitis may have a protective effect on alveolar bone during the early stages of periodontitis. In SP patients, however, the reduced level of azurocidin may lose its protective effect, which may lead to increased alveolar bone loss during later stages of periodontitis.

\section{Conclusions}

Our GCF proteomic study suggests that GCF collection using a gel loading tip followed by LC-MS/MS analysis is a useful method for analyses of periodontitis GCF biomarkers. Our data have revealed that azurocidin may be a potential biomarker candidate for the early detection of periodontal destruction by the inflammation in gingivitis and some chronic periodontitis based on the mass spectrometry, western blot and ELISA data using GCF samples. In addition, we have shown that azurocidin may have an inhibitory role on osteoclast differentiation, which suggests that azurocidin may decrease alveolar bone loss during periodontitis.

\section{Additional material}

Additional file 1: Information for samples used for the identification of the GCF proteome using LC-MS/MS

Additional file 2: Information for samples used for the ELISA assay of azurocidin.

Additional file 3: List of 305 proteins identified from the combined analysis of both N and MP samples.

Additional file 4: Information about the identified bacterial protein in GCF that was obtained by searching the NCBI database for bacteria known to cause periodontitis.

\section{Abbreviations}

CAP37: cationic antimicrobial protein of 37 kDa; CAPs: cationic antimicrobial proteins; HBP: heparin-binding protein; GCF: gingival crevicular fluid; LPS: lipopolysaccharide; PMN: polymorphonuclear granulocyte; PPD: probing pocket depth; BOP: bleeding on probing; Gl: gingival index; GV: gingivitis; MP: moderate periodontitis; SP: severe periodontitis.

\section{Acknowledgements}

This work was supported by the Korea Health 21 R\&D Project, Ministry of Health \& Welfare, Republic of Korea (Grant No. A090610), and by the National Research Foundation of Korea (NRF) from the Ministry of Education, Science and Technology (MEST), Republic of Korea (Grant No. 20100020544, 20100029494).

\section{Author details}

${ }^{1}$ Department of Biochemistry, School of Dentistry, Kyungpook National University, Daegu, Korea. ${ }^{2}$ Department of Periodontology, School of Dentistry, Kyungpook National University, Daegu, Korea.

\section{Authors' contributions}

JC was responsible for planning and designing the study, data interpretation and revising the manuscript. YC performed the experiments and the data analysis and wrote the manuscript. SH participated in designing the experiments and writing the manuscript. $J$ was responsible for the collection of the GCF and gingival tissues. All authors read and approved the final manuscript.

\section{Competing interests}

The authors declare that they have no competing interests.

Received: 28 February 2011 Accepted: 28 July 2011

Published: 28 July 2011

\section{References}

1. Kinney JS, Ramseier CA, Giannobile WV: Oral fluid-based biomarkers of alveolar bone loss in periodontitis. Ann N Y Acad Sci 2007, 1098:230-251.

2. Albandar JM: Periodontal diseases in North America. Periodontol 2000 2002, 29:31-69.

3. Danesh J, Collins R, Peto R: Chronic infections and coronary heart disease: is there a link? Lancet 1997, 350:430-436.

4. Seymour GJ, Ford PJ, Cullinan MP, Leishman S, Yamazaki K: Relationship between periodontal infections and systemic disease. Clin Microbiol Infect 2007, 13(Suppl 4):3-10.

5. Demmer RT, Behle JH, Wolf DL, Handfield M, Kebschull M, Celenti R, Pavlidis P, Papapanou PN: Transcriptomes in healthy and diseased gingival tissues. J Periodontol 2008, 79:2112-2124.

6. Hefti AF: Periodontal probing. Crit Rev Oral Biol Med 1997, 8:336-356.

7. Bragger U: Radiographic parameters: biological significance and clinical use. Periodontol 2000 2005, 39:73-90.

8. Loos BG, Tjoa S: Host-derived diagnostic markers for periodontitis: do they exist in gingival crevice fluid? Periodontol 2000 2005, 39:53-72.

9. Offenbacher S, Barros SP, Beck JD: Rethinking periodontal inflammation. J Periodontol 2008, 79:1577-1584.

10. Embery $G$, Waddington R: Gingival crevicular fluid: biomarkers of periodontal tissue activity. Adv Dent Res 1994, 8:329-336. 
11. Lamster IB, Ahlo JK: Analysis of gingival crevicular fluid as applied to the diagnosis of oral and systemic diseases. Ann N Y Acad Sci 2007, 1098:216-229.

12. Champagne CM, Buchanan W, Reddy MS, Preisser JS, Beck JD, Offenbacher S: Potential for gingival crevice fluid measures as predictors of risk for periodontal diseases. Periodontol 2000 2003, 31:167-180.

13. Armitage GC: Analysis of gingival crevice fluid and risk of progression of periodontitis. Periodontol 2000 2004, 34:109-119.

14. Hu S, Loo JA, Wong DT: Human body fluid proteome analysis. Proteomics 2006, 6:6326-6353.

15. Pradeep AR, Kumar MS, Ramachandraprasad MV, Shikha C: Gingival crevicular fluid levels of neopterin in healthy subjects and in patients with different periodontal diseases. J Periodontol 2007, 78:1962-1967.

16. Heo SH, Lee SJ, Ryoo HM, Park JY, Cho JY: Identification of putative serum glycoprotein biomarkers for human lung adenocarcinoma by multilectin affinity chromatography and LC-MS/MS. Proteomics 2007, 7:4292-4302.

17. Park HJ, Kim BG, Lee SJ, Heo SH, Kim JY, Kwon TH, Lee EB, Ryoo HM, Cho JY: Proteomic profiling of endothelial cells in human lung cancer. J Proteome Res 2008, 7:1138-1150.

18. Park ES, Cho HS, Kwon TG, Jang SN, Lee SH, An CH, Shin HI, Kim JY, Cho JY: Proteomics analysis of human dentin reveals distinct protein expression profiles. J Proteome Res 2009, 8:1338-1346.

19. Keller A, Nesvizhskii Al, Kolker E, Aebersold R: Empirical statistical model to estimate the accuracy of peptide identifications made by MS/MS and database search. Anal Chem 2002, 74:5383-5392

20. Nesvizhskii Al, Keller A, Kolker E, Aebersold R: A statistical model for identifying proteins by tandem mass spectrometry. Anal Chem 2003, 75:4646-4658.

21. Cho JY, Lee M, Ahn JM, Park ES, Cho JH, Lee SJ, Kim BG, Heo SH, Park HJ, Zerbini LF, et al: Proteomic analysis of a PDEF Ets transcription factorinteracting protein complex. J Proteome Res 2009, 8:1327-1337.

22. Seul KJ, Cho HS, Heo SH, Baek WY, Kim JE, Park EK, Choi JY, Ryoo HM, Cho JY: Osteoblast-specific expression of MEF induces osteopenia through downregulation of osteoblastogenesis and upregulation of osteoclastogenesis. J Bone Miner Res 2010, 26:341-350.

23. Soehnlein $\mathrm{O}$, Lindbom L: Neutrophil-derived azurocidin alarms the immune system. J Leukoc Biol 2009, 85:344-351.

24. Soehnlein $\mathrm{O}$, Xie $\mathrm{X}$, Ulbrich $\mathrm{H}$, Kenne E, Rotzius P, Flodgaard H, Eriksson EE, Lindbom L: Neutrophil-derived heparin-binding protein (HBP/CAP37) deposited on endothelium enhances monocyte arrest under flow conditions. J Immunol 2005, 174:6399-6405.

25. Pisano E, Cabras T, Montaldo C, Piras V, Inzitari R, Olmi C, Castagnola M, Messana I: Peptides of human gingival crevicular fluid determined by HPLC-ESI-MS. Eur J Oral Sci 2005, 113:462-468.

26. Ngo LH, Veith PD, Chen YY, Chen D, Darby IB, Reynolds EC: Mass spectrometric analyses of peptides and proteins in human gingival crevicular fluid. J Proteome Res 2010, 9:1683-1693.

27. Bostanci N, Heywood W, Mills K, Parkar M, Nibali L, Donos N: Application of Label-Free Absolute Quantitative Proteomics in Human Gingival Crevicular Fluid by LC/MS(E) (Gingival Exudatome). J Proteome Res 2010, 9:2191-9.

28. Zimmer M, Medcalf RL, Fink TM, Mattmann C, Lichter P, Jenne DE: Three human elastase-like genes coordinately expressed in the myelomonocyte lineage are organized as a single genetic locus on 19pter. Proc Natl Acad Sci USA 1992, 89:8215-8219.

29. Shafer WM, Martin LE, Spitznagel JK: Cationic antimicrobial proteins isolated from human neutrophil granulocytes in the presence of diisopropyl fluorophosphate. Infect Immun 1984, 45:29-35.

30. Watorek W: Azurocidin - inactive serine proteinase homolog acting as a multifunctional inflammatory mediator. Acta Biochim Pol 2003, 50:743-752.

31. Almeida RP, Vanet A, Witko-Sarsat V, Melchior M, McCabe D, Gabay JE: Azurocidin, a natural antibiotic from human neutrophils: expression, antimicrobial activity, and secretion. Protein Expr Purif 1996, 7:355-366.

32. Heinzelmann M, Platz A, Flodgaard H, Miller FN: Heparin binding protein (CAP37) is an opsonin for Staphylococcus aureus and increases phagocytosis in monocytes. Inflammation 1998, 22:493-507.

33. Campanelli D, Detmers PA, Nathan CF, Gabay JE: Azurocidin and a homologous serine protease from neutrophils. Differential antimicrobial and proteolytic properties. J Clin Invest 1990, 85:904-915.

34. Rasmussen PB, Bjorn S, Hastrup S, Nielsen PF, Norris K, Thim L, Wiberg FC, Flodgaard $\mathrm{H}$ : Characterization of recombinant human HBP/CAP37/ azurocidin, a pleiotropic mediator of inflammation-enhancing LPSinduced cytokine release from monocytes. FEBS Lett 1996, 390:109-112.

35. Lorenzo J, Choi Y: Osteoimmunology. Immunol Rev 2005, 208:5-6.

36. Takayanagi $\mathrm{H}$ : Osteoimmunology: shared mechanisms and crosstalk between the immune and bone systems. Nat Rev Immunol 2007, 7:292-304.

37. Theill LE, Boyle WJ, Penninger JM: RANK-L and RANK: T cells, bone loss, and mammalian evolution. Annu Rev Immunol 2002, 20:795-823.

38. Walsh MC, Kim N, Kadono Y, Rho J, Lee SY, Lorenzo J, Choi Y: Osteoimmunology: interplay between the immune system and bone metabolism. Annu Rev Immunol 2006, 24:33-63.

doi:10.1186/1477-5956-9-42

Cite this article as: Choi et al:: Identification of azurocidin as a potential periodontitis biomarker by a proteomic analysis of gingival crevicular fluid. Proteome Science 2011 9:42.

\section{Submit your next manuscript to BioMed Central and take full advantage of:}

- Convenient online submission

- Thorough peer review

- No space constraints or color figure charges

- Immediate publication on acceptance

- Inclusion in PubMed, CAS, Scopus and Google Scholar

- Research which is freely available for redistribution

Submit your manuscript at www.biomedcentral.com/submit
Biomed Central 